\title{
Sociological Research of the Career Education
}

\author{
Baoshu Zhang \\ Faculty of Education, Qufu Normal University \\ Qufu 273165, China \\ Tel: 86-537-488-8175 E-mail:zhangda007@163.com
}

The research is financed by the project of the Qufu Normal University Scientific Research Fund (No. XJ200810). (Sponsoring information)

\begin{abstract}
In 1970s, the US career education achieved significant development and produced extensive and deep influences under the supports of the public. As viewed from the sociology, the production and development of the career education is induced by the deep social factors. The opening integrated career system supported by the school, the community and the enterprise is the effective measure to solve the problems such as social equity and the continually ascending unemployment rate.
\end{abstract}

Keywords: Career education, Social equity, Equal opportunity

\section{Introduction}

The career education is the education taking the occupational education and labor education as the core, and it was first put forward by the director-general of American Education Agency, Sydney Maran in Jan of 1971 when he delivered a speech in the National Association of Secondary School Principals Convention of Houston. Maran thought that the American society was in the new change stage, and the change of the society decided the education was not for the permanent occupation, and people would change the occupation time after time, and sometimes the span among occupational conversions was very large, and these conversions required people to learn many sorts of new knowledge and skills in order to adapt the requirements of the survival in the changeable society. Maran's education concept won many responses and supports, which raised a dynamic education reform movement in US. This reform produced impressive influences in America. Chinese scholars introduced and studied this reform from two layers such as the education history and the occupational education. For example, when Mr. Wang Tianyi introduced the thoughts of "permanent education" in the book of "Foreign Education History", he said "under the theoretical influence of permanent education, in 1971, the director-general of American Education Agency, Maran put forward the theory of "career education", and it is a sort of education opinion taking the occupation and labor as the core, and it requires combining the common school education with occupational education in the implementation, and implementing this sort of education form into all grades from elementary school, middle school and even colleges (Wang, 1993, P.98)". When Professor Wu Shiying introduced the education reform in 1970-1980 in his book of "Foreign Education History Tutorial", he simply introduced the American career education and summarized that "the career education is the reflection of people's anxiety-ridden senses on the education system when the social unemployment rate in US is higher (Wu, 1999, P.632)". Mr. Liu Yibing introduced the production background, concept and implementation mode of the career education in the article of "American Career Education Movement" in the fourth volume of "Foreign Education Trends" of 1988. Mr. Ma Jixiong introduced the career education in the book of "Post-war US Education Research". In the book of "Restless Hundred Years", Professor Lu Youquan also simply introduced the career education. The introduction and explanation about the career education on the layer of the occupational education were in various journals of occupational education, and most of these contents are repeated with the study of the education history. Whether the introduction of the education history or the occupational education all produced the active influences in Chinese education academy, but the career education was still not emphasized enough in China, and the elementary school, the middle school even the whole society don't emphasized the career education enough. With the further development of Chinese economy, many social problems such as educational opportunity equity and ascending unemployment rate also occurred. Therefore, it is very important to analyze and survey the career education of US from the view of sociology. 


\section{Career education: the education approach to solve the social problems by US}

On the surface, the career education is an educational phenomenon, but it is not single educational problem in fact. It was the complex reflection that the deep conflicts in US society were difficult to be harmonized, and it was a sort of test and exploration of the education when other solutions were not effective.

\subsection{The social background of the career education}

In Jan of 1964, US president Johnson alleged that "fight the poor of US unconditionally" in the State Message. A half year later, he persuaded the congress to pass the economic opportunities proposed law supports his idea. After that, he put forward the idea of "great society" and the administration political program. Johnson emphasized that the education was the key to fight the poor and realize the "great society". First, though the ex-president Kennedy's economic policy stimulated the growth of the US economy, but the unemployment rate still remained high and not fallen, especially in the depressed region induced by the decline of traditional industrial departments and the structured unemployment influenced by the science and technology revolution, the problem were more serious. That made the Johnson administration introduced the human resource development and utilization to realize the target of sufficient employment through many structured measures such as education, occupational training and developing the undeveloped regions. Second, the Johnson administration also wanted to realize the selection promises through the measure of anti-poor, implement the social equity and opportunity equity to clam down electorates' dissatisfactions and bring the Chartism into the channel of governmental control. Third, "fight the poor" also wanted to make the poor people who depended on the help of the government obtain the work again through the educational measures, and reduce the burdens of the federal government.

On the surface, the economic opportunity proposed law didn't involve the education, but its most contents were constituted surrounding the education. The first aspect was the children and youth education plan. In the plan, the government should carry through the pre-school education for the children from 3 years old to 6 years old, should implement the free tutorship for the senior high school students in poor family to enhance their proportions of students entering schools of a higher grade, and should offer temporary works for about 140 thousands youths to make them pay the college tuition fees by the federal capitals. The second aspect was the occupational training and the re-training plan. In the plan, the government should establish the occupational training camp which could offer two year's occupation training and basic skill training for the youth employments from 16 years old to 21 years old, and appoint them to engage in the work of natural resource protection. And the government should appoint the youth volunteers in the US Volunteer Corps to the poor regions, madhouse, school and Indian reservation to serve from poor people and minority, and the central government authorized the state governments and local governments to organize the youth unemployment as the street youth team and make them serve for local communities and reduce the juvenile crime rate. The third aspect was the community action plan. The congress was authorized to appropriate funds of 945 millions dollars to implement the economic opportunity proposed law in the first year (Liu, 2002, P.240-241). After that, in 1964-1965, the national education outlay had achieved record-breaking 39 billion dollars, but there were still many Americans could not support their children to obtain sufficient educational opportunities. In April of 1968, the "Elementary and Second Education Act" was passed, and the limitation that the large amount assistance to the elementary and middle education funds by the federal administration was broken, and the federal administration could largely develop and popularized the education through the financial funds to make children in the poor families and minority families obtain the educational opportunities and break away from the poor situations.

However, the favorable desires didn't equal the beautiful reality, and the education was not the catholicon to cure various social illnesses. Above reform measures certainly could reduce the unequal opportunities such as the sex, the race and the age, and offer the opportunities with higher social status and well treatment for all citizens. But the administration still seriously ignored the fact, i.e., in the influences of these many complex social factors, the equity of the opportunities didn't equal the equity of the competitive results. In the capitalistic US with drastic competition, the single opportunity equity based on individual ability only would induce the polarization in fact. Based on above factors, as the approach to solve he social problems in US, the "career education" started.

\subsection{The career education is the measure to realize the social equity}

In the middle of $1960 \mathrm{~s}$, because of the impact of the postwar science and technology revolution, the quick development of the industrial society and the raise of the negro movement, many problems such as the poverty, the structured unemployment, the racialism, unequal rights and opportunities, especial for the high employment existing in the US society became into the social focus after the economic crisis in the twenties and thirties. People had not treated it simply from the economic view, but surveyed it from many social views such as race equity, social equity, education opportunity equity, education right and poverty. People had not treated the material fortune or natural wisdom and physique as the main reason of the income, and they thought that the normal development of individual talents and skills as the necessary factors to obtain the success. Therefore, in the face of so many social problems, especially in the face of the problem of the high unemployment rate, people begun to reconsider the traditional education and the 
occupational education. The public of US, especial the Negro society and the representatives from the Negro society, the minority and the middle and lower society, and their supporters appealed that the education should eliminate the social inequity and the opportunity inequity.

By force of the social pressure, the US administration adopted many measures such as increasing the national educational outlay and strengthening the educational legislation to extend the opportunity that the youths accepted the education, help the child in the low-income and minority families to obtain better education and walk out the poverty and eliminate the obstacles in the individual and social developments. However, above sorts of endeavors didn't obtain anticipated effects. In the book of "The Theory of Education Opportunity from 1960-1975", Church wrote that "the poor children and some minority children can not use same establishments like the children in the prerogative group... in 1960s, the education must explain that why the equal opportunities can not induce equal results (Qu, 1990, P.440)". To change the "equality of opportunities" to the "equality of results", the administration implemented multiple reforms, and the career education proposed by Maran was the educational reform exploitation in the common education domain to realize the equal results and "make all children obtain various employment opportunities".

The theoretical hypothesis of the career education is that the responsibility of the school should offer the skills, motives and opportunities to detect and discover various careers for students. The career education is not a sort of subject, and not the new name of the occupational education. And it is a sort of education concept traversing all subjects and domains. The basic meanings of the career education includes following aspects. First, every class teacher in various-level education should emphasize the career meaning of the essential contents in the proper place. Second, put forward the occupational skill training to enter into the occupational world again successfully. Third, set up the comprehensive career development plan including the active cooperation and participation of school personnel and non-school personnel. Fourth, offer many opportunities such as work observation, work experience and part work for students and peoples in the public schools, and offer consultation services about the character and the demand of the occupational community for school officers. Fifth, admit and utilize the mutual relationships among families, communities and occupational leagues. In the "Direction Handbook", US Federal Education Agency alleged that "the so-called career education is to unify various social values in the labor into the individual structure of personality value, and make the labor become into the labor shared and enjoyed by everyone. The intention of the public education and the endeavors of all members in the region or the community would help everyone to realize these social values in the living (Liang, 1986, P.458)".

American Federal Education Agency treated the career education as the important measure and approach to help every one in the living to realize above social values, but this measure was not efficient in one day, and it needed to pass a systematical education process with grading. In this process, it made every student possess the target of self devleop0ment and made him find out his own position in the social labor and living. Therefore, US educational experts divided 23,000 social occupations into 15 career groups, i.e. the business and office, the sale promotion and retail, the communication and press medium, the building industry, the manufacturing, the traffic and transportation, the agricultural business and natural resource, the navigation, the environmental protection, the public utility, the sanitation, the tour amusement, the private service, the arts, the humanism consumption and domestic economy. We could see that these "career groups" contained all industries in the social life. And this sort of career education ran through the whole education plan from the kindergarten to the college, and it faced all students, and it also included the adult and successive education to make them be familiar with various careers and grasp or select the ability of the career (Fuller, 1979, P. 44). In addition, the career education also required all establishments in the schools should face all students. So, the exponentials of the career education wanted to not only obtain students' successes or better careers to show the result equity of the education through the implementation of the career education accruing to the students' individual differences, but also make students fully enjoy the educational resources and realize the social equity in the educational process. However, based on the US social reality then, the result was only exponentials' own wishful thinking.

\section{Career education: the integrated education supported by the school, the family and the community}

The career education is not a sort of concrete subject, and not the name of certain occupational education. Like the comprehensive technological education concept of former Soviet Union, it is a sort of free education (liberal education). Though the career education has its own target, but the implementation of the target should draw support from other subjects. And the every subject established in the school should integrate with the concept of the career education. Teachers and school should utilize all conditions and establishments in the school and out the school to make students obtain their favorite occupational trainings. In the practical teaching process, the abstract knowledge should associate with the practical works, and the relationship between the common education and the occupational education should be treated correctly. The educational practice leaded by the concept is a macro system engineering which can not be completed only depending on the school, and it must be implemented by the communal participations of the family, community and other industries. To better implement the career education, effectively harmonize the relation among the school, the family and the community and confirm their own responsibility and obligations, the US administration 
successively issued "the Elementary and Middle School Education Law", "the Career Education Act", and the "Vocational Education Act". After that, various states also successively issued local laws and regulations about the career education. The issuances of the laws and regulations offered the possibility to favorably implement the career education for the federal government, and offered legal references for large amount funds of the career education. These laws and regulations also definitely confirmed the various responsibilities and obligations of the schools, families and communities to implement the career education. Under the legal guidance and restriction, the American Federal Education Agency set about to develop the career education mode based on the schools, the employments, the families and the communities.

The career education based on school is the main form of the career education, and it is mainly limited in the stage from the kindergarten to the senior high school, and the development of the career education needs the participations from various parties in the society which should establish extensive cooperation plans with the school, and the target of the career education is to make all students to learn the updating education course, contact various occupations, ensure every student obtain the education combining the academic course with the occupation preparation, and obtain employment or keep on enter a higher school when he graduates or dropped out. The education mode based on the employer is the learning mode to offer the high school students from 13 years old to 18 years old for the occupation training, and it makes students obtain knowledge skills to replace the traditional course teaching in virtue of the actual employment offered by the public or private enterprisers, and students can obtain corresponding credit hours through completing the courses offered by the enterprisers, and the school brings the credit hours into the total grade. The education mode based on family and community is the education system taking the family community as the center, and it offers career consultation, career direction and work arrangement and relative education course information. The career education based on dwelling district mainly assist with the village poor denizens lacking in education and occupation selections or the families in the bad social situation, and this education mode calls together these denizens and makes them to obtain employments or further education opportunities. Both former modes face the school students, and later two modes mainly face the society. So we can see that the implementation of US career education is to lead various education modes including the basic education, the higher education, the occupational education, the adult education and the national education by the idea of the career education. The career education is the complex "integrated" system facing not only students but also the social unemployment, and it possesses the characteristics such as comprehension, cooperation and work-study.

\section{Career education: an opening social system}

The open system theory thought that "the organization is the sustainable system to adjust its survival through the input and the output between it with the environment (Martin, 2005, P.154)". As viewed from the open system theory, the career education is not only the "integrated" system with participants including schools, families and communities, but an open social system. This system includes the inputs from the social environment such as the social values, beliefs, anticipated targets, technical skills, knowledge experiences, capitals and equipments, the process of the career education including the teaching process, the information exchange and the energy conversion process, the outputs of the "integrated" system to the society which are mainly embodied in the contributions that the individual with certain career ability do for the society. This process can be denoted by the Figure 1 .

As viewed from the open system theory, the "integrated" system of the US career education possesses some characteristics of the opening system organization. First, it is a dynamic cycle system, because the career education process is composed by cycle systems one by one and the big cycle system includes small cycle systems such as the time cycle, the school year cycle, the week cycle, the day cycle, and the course hour cycle. Second, the career education is a balanced system which can be adjusted by it. The career education should keep a sort of balance with the environment. When the surrounding environment acts on the system, it will certainly react. To sustain this sort of balance status, the career education system sometimes will pay out biggish costs such as adjusting the education policy, modifying the education contents, even re-modifying the intention and the target of the education. Third, the career education has the information input and feedback system. The career education system can exactly judge the "products" from it and feed back to relative departments or the subsystem in time for the further adjustment and perfection.

Of course, the US career education still has problems. In fact, like other things, it still has its deficiencies and limitations, for example, it overemphasizes the knowledge with material gains, which threatens the free education. And someone censured that in the recessionary economy of US would be further destroyed when it enhanced youths' interests for the outdated works. But many American educationists thought it would be able to lighten some urgent social, economic and educational problems, and it would deeply influence the youths' self-realization. Therefore, the US society didn't stop the career education because of the deficiencies or the comments in the career education. In 1994, the US Congress passed the "the Opportunity Law from School to Work" to further drive the implementation of the career education, and the law required when the schools offered the common education for students, they should impart students concrete career skills to ensure them favorably arrive in the "work world". 


\section{References}

Fuller, Jack W. \& Terry Whealon. (1979). Career Education: a Lifelong Process. Nelson Hall Inc. 1979. P. 44.

Liang, Zhongyi. (1986). Occupational Technology Education Manual. Changchun: The Northeast Normal University Press. P.458.

Liu, Xuyi, Hantie \& Li, Cunxun (interpreted). (2002). Postwar America History (American Comprehensive History). Beijing: People's Publishing House. P.240-241.

Martin, Hanson, interpreted by Feng, Daming (2005). Education Management and Organization Behavior. Shanghai: Shanghai Education Press. P.154.

Qu, Baokui. (1990). American Education Reform (Education Science Corpora). Beijing: People's Education Press. P.440.

Wang, Tianyi, Xia, Zhilian \& Zhu, Meiyu. (1993). Foreign Education History (Book Two). Beijing: Beijing Normal University Press. P.98.

Wu, Shiying, Li, Mingde \& Shan, Huizhong. (1999). Foreign Education History Tutorial. Beijing: People’s Education Press. P.632.

Inputs from social environment $\longrightarrow$ Career education process $\longrightarrow$ Outputs to the society

\begin{tabular}{|c|c|c|}
\hline $\begin{array}{l}\text { 1. Students } \\
\text { statistic population } \\
\text { subculture, variable, } \\
\text { groups, class) } \\
\text { 2. Teampeer } \\
\text { (teaching adming personnel } \\
\text { manager, assistant teaching } \\
\text { personnel, training, class } \\
\text { background, affiliation) } \\
\text { 3. Family } \\
\text { 4. Community (education } \\
\text { administration, various } \\
\text { industrial owners and } \\
\text { teams) a }\end{array}$ & $\begin{array}{l}\text { Integrated career education } \\
\text { system } \\
\text { 1. Structure (normal and } \\
\text { abnormal role relations) } \\
\text { 2. Target } \\
\text { 3. Plans (content, course } \\
\text { plan, test system) } \\
\text { 4. System process } \\
\text { (socialization, teaching } \\
\text { decision communication } \\
\text { system, career selection } \\
\text { training system, discipline, } \\
\text { transformation, adaptation) } \\
\text { 5. Abnormal structure }\end{array}$ & $\begin{array}{l}\text { 1. Graduates, under } \\
\text { graduate and drop-out with } \\
\text { living ability } \\
\text { 2. New knowledge } \\
\text { 3. New culture } \\
\text { 4. New skills and } \\
\text { technologies } \\
\text { 5. Old information }\end{array}$ \\
\hline
\end{tabular}

Figure 1. Career Education: Integrated System Supported by Family and Community 